\title{
Evaluation of morphological parameters and bioactive compounds in different varieties of beetroot (Beta vulgaris L. ssp. esculenta GURKE var. rubra L.)
}

\author{
Rubóczki, T. ${ }^{1}$, Raczkó, $V^{2}{ }^{2}$ \& Takácsné Hájos, M. $^{1}$ \\ ${ }^{1}$ University of Debrecen, Faculty of the Agricultural and Food Sciences and Environmental Management, \\ Horticulture Department, H-4032 Debrecen, Böszörményi Street 138. \\ ${ }^{2}$ University of Debrecen, Centre of Agricultural Science, H-4032 Debrecen, Böszörményi Street 138. \\ E-mail: ruboczkit@agr.unideb.hu
}

\begin{abstract}
Summary: Beetroot consumption based on pickled beets generally in Hungary which is due to the higher yield from second crop harvested in autumn and processed by manufacturing industry. Researches of the past years confirmed its favourable nutritional-physiological effects on human body so demands, as for fresh salad, also increased. The trial aimed at testing the interaction of varieties on quality parameters and in the same time suggestions are made how to use different varieties of beetroot according to its quality. Morphological and sensory evaluations were examined on 10 varieties of beetroot harvested in autumn. The regular spherical shape can reduce the refining loss during the processing of beetroot which is beneficial for the manufacturing industry. In our trial the root shape of Libero, Mona Lisa and Rubin varieties approached most the regular spherical shape (diameter/length - 1.0) which is favoured by not only processing industry but also fresh market. The highest red pigment content (betanin) was observed in Mona Lisa, Akela and Cylindra (34.58-47.66 mg/100 g). A similar trend could be observed in yellow pigments (vulgaxanthins) which proves the close correlation between the quantities of the two pigments ( $\mathrm{r}=0.898)$. Highest total polyphenol (77.13-83.37 mg GAE/100g) and flavonoid (21.73-22.73 mg CE/100g) contents were detected in Akela, Mona Lisa and Bonel. These varieties are favourable for fresh salad and they can satisfy processing requirements also. Highest water soluble solids content was found in Akela (7.15\%). In our conditions nitrate $\left(\mathrm{NO}_{3}-\mathrm{N}\right)$ values below $900 \mathrm{mg} / \mathrm{kg}$ were examined in all of the varieties which is favourable in the case of beetroot.
\end{abstract}

Keywords: beetroot varieties, betanin, bioactive compounds, growing, nitrate content, total polyphenol content, vulgaxanthin

\section{Introduction}

Red beet can increase not only the stamina, but also it helps to improve the carrying capacity of muscles. Moreover, it contains high amount of antioxidants and water-soluble fibre which makes it more important for us (Bailey et al., 2009).

The beetroot accumulates many nutrients. As the red beet contains mineral silica, it helps the body to utilise calcium, which is important for the health of human musculoskeletal system and reducing the risk of osteoporosis. Furthermore, it makes the connective tissue, the skin and the wall of blood vessels stronger and it detoxifies the human body from the harmful substances (Hyun et al., 2009; Green, 2011).

Known to be as a natural organic food colouring (ice cream, yoghurt, sausage) which means that the red pigments can be used for replace the carcinogenic artificial food dye with sign E123. The betanin is a red food dye obtained from beets and as a food additive, its E number is E162 (Takácsné Hájos, 2009).

Many studies had to be done in the past decades to realize again how important this plant is for us.
First of all, Ferenczi (1970) demonstrated that the red betanin which is obtained from the beet has an anticarcinogenic effect on patients with cancer. Researchers proved this effect which is owing to the lactic acid content of fermented products from red beet and vitamins $\mathrm{C}$ and E. Betanin is one of the most important antioxidants from beetroot which can help to reduce the oxidation of LDL cholesterol, in turn protecting artery walls and reducing the risk of heart disease and stroke (Samman, 2003).

Beetroot juice can help reduce blood pressure because of the high content of nitrates in beetroot produce a gas called nitric oxide in the blood which widens blood vessels and lowers blood pressure (Kapil et al., 2010; Green, 2011). A daily dose of $250 \mathrm{ml}$ of beetroot juice or 1 to 2 cooked beetroot (approx. $100 \mathrm{~g}$ ) can help dramatically reduce blood pressure and its associated risks. Furthermore, a recent study by Wake Forest University in North Carolina, USA showed that the high content of nitrates with folic acid in beetroot may also help to fight the progression of dementia and to protect against Alzheimer's disease (Presley et al., 2011; Green, 2011). 
It is known that $100 \mathrm{~g}$ beetroot is enough to cover $75 \%$ of Reference Daily Intake from folic acid which is essential for normal tissue growth and it can help to prevent spinal cord defects such as spina bifida during the first three months of pregnancy (Green, 2011).

The red beet acquired more popularity when some athletes in the 2012 Olympic Games improved their performance by 16\% (Bryan \& Pierini, 2013).

Most importantly the beetroot is effective on all parts of the human body because of the high content of powerful antioxidants and phenolic compounds.

Despite of the fact that red beet is so valuable for us, the growing area in Hungary is not even 400 hectare which is approx. $0.3 \%$ of the total vegetable area. The yield of red beet from this field is between 7,000 and 10,000 tons, which is going to be mostly pickled beets, beetroot juice or food colorant by the manufacturing industry. France and the United Kingdom can produce the highest yield of beetroot where it is more than 90,000 tons per year (Hraskóné \& Tóthné Taskovics, 2011).

The natural and weather conditions are excellent to growing beetroot in Hungary and the customer requirements had shown more interest in the last years, but we should broaden our horizons and the consumption opportunities (Takácsné Hájos, 2011).

The consumption of red beet is so varied in Europe and the United Stated of America where we can find not only raw red beet but also freshly cooked beets which can be used for salads, desserts and for soups.

The quality of red beet is determined by the inner colour intensity, the uniformity and the water soluble solids content primarily. Red pigments are found in several components which are present in different proportions in the varieties. They also determine the pigment compositions and their stability. Betanin is the main component of betacyanins, and it takes $75-95 \%$ of this.

One of the unfavourable traits is white ring, which can be reduced considerably by proper cultural methods. The geosmin (tranz 1.10-dimethyl-trans-decalol) is produced by fungal spores of Actinomycetes which is responsible for the characteristic earthy taste of beetroot. The accumulation of this compound is depend not only on the soil and the variety, but also on storage conditions and processing technology.

In addition to domestic varieties we can use foreign varieties also. The colour intensity of this varieties can be unfavourable, but the thin bottom root make a good quality for the industry (Takácsné Hájos, 2011).

\section{Materials and methods}

Our experiment was carried out in the Horticultural Demonstration Garden of Centre for Agricultural Sciences of the University of Debrecen in 2012. Test was set up with 10 varieties of beetroot at 26 June sowing date (Table 1). The parcels size were $4 \mathrm{~m} \times 0.6 \mathrm{~m}$ with $2-2$ rows per type.
Morphological and sensory evaluations were examined. The trial aimed at testing the interaction of varieties on quality parameters and in the same time suggestions are made how to use different varieties of beetroot according to its quality.

Table 1. The examined varieties and their type of beet

\begin{tabular}{|c|l|c|}
\hline Number & \multicolumn{1}{|c|}{ Variety } & Type of beet \\
\hline 1 & Bíborhenger & cylindrical \\
\hline 2 & Bonel & spherical \\
\hline 3 & Rubin & spherical \\
\hline 4 & Detroit 2 & spherical \\
\hline 5 & Akela & spherical \\
\hline 6 & Larka & spherical \\
\hline 7 & Libero & spherical \\
\hline 8 & Mona Lisa & spherical \\
\hline 9 & Kornett & spherical \\
\hline 10 & Cylindra & cylindrical \\
\hline
\end{tabular}

During the growing period the usual cultural and weeding methods were used. Plants were thinned at the 2-4 leaf stage. Preventive spraying were applied to protect the plants against flea beetle and fungal diseases. Crop was harvested 9 October 2012. Field measurements and sensory evaluations included: leaf length $(\mathrm{cm})$, leaf weight $(\mathrm{g})$, root diameter $(\mathrm{cm})$, root length $(\mathrm{cm})$, root weight $(\mathrm{g})$, inner colour intensity (1-5), white ring (1-3) and taste (1-5). Pigment content $(\mathrm{mg} / 100 \mathrm{~g})$ was measured in the Central Laboratory of the University of Debrecen, Centre of Agricultural Science with spectrophotometer at $\lambda=476 \mathrm{~nm}$, $\lambda=538 \mathrm{~nm}$ and $\lambda=600 \mathrm{~nm}$ wavelength. The pigment content was determined according to Nilsson (1970) from the obtained extinction values (mg/100g fresh matters). Total polyphenol content of beetroot samples were determined by the FolinCiocalteu method (Lamaison \& Carnat, 1990). Gallic acid (GA) was chosen as a standard and the data were expressed as milligram gallic acid equivalents (GAE)/100 $\mathrm{g}$ fresh matter of beetroot. Flavonoid content was determined according as the colorimetric method described by Lamaison \& Carnat (1990). Catechin was chosen as a standard. The data were expressed as milligram catechin equivalents (CE)/100 g fresh matter of beetroot. Spectrophotometric method was used to determine the nitrate content in the samples. The data for beetroot were expressed as $\mathrm{mg} / \mathrm{kg} \mathrm{NO}_{3}-\mathrm{N}$ (Abrankó et al., 2010). To examine the total solids content we had to dry the samples on $104{ }^{\circ} \mathrm{C}$. The data were expressed as percent. A digital refractometer was used to measure the water soluble solids content in ${ }^{\circ}$ Brix. The measurements were made at room temperature.

\section{Results}

\section{Root morphology}

The examination of morphological parameters of the varieties has practical significance. Quality is affected 
considerably by the morphological parameters of the root. The tested varieties were all of the spherical type except for Biborhenger and Cylindra. The spherical or slightly flatted root shape has an attractive appearance which is important for the fresh market. In the spherical type varieties the regular spherical shape with about 1.0 shape index is favourable. In our trial favourable shape index was observed in Libero, Mona Lisa and Rubin (Figure 1). Shape is influenced by the uniform water supply of the soil affecting the activity of the bottom root. Temporary water deficiency can make the bottom root thicker and heart- or oval shaped which is unfavourable for the processing because the cleaning loss will increase.

Beetroot varieties with intensive root thickening and smaller leaves are expected. Higher yield can be achieved by them. In our experiment Mona Lisa has excelled in morphological parameters.

\section{Quality parameters}

The raw material value of beetroot is determined principally by the pigment content, its even distribution and the correlation of the red betacyanin (BC) and yellow betaxanthin (BX) pigments to each other.

Important quality parameters the total polyphenol-, the flavonoid-, the total solids- and the nitrate contents which also determine the nutritional value of the beetroot variety. The difference of the accumulation of these parameters between the varieties had been tested by our experiment.

The pigment content is the main important parameter which is determined by two pigment groups (BC and $\mathrm{BX}$ ). The most important pigment component is the betanin, a compound of red betacyanins occurring in the highest ratio which can help to decrease the risk of heart disease and stroke by reducing the oxidation of LDL cholesterol (Samman, 2003). The higher betanin content was promoted by the lower air temperature at the time of root thickening (September, in the second crop). It means that the cooler temperature affects the pigment synthesis favourably.

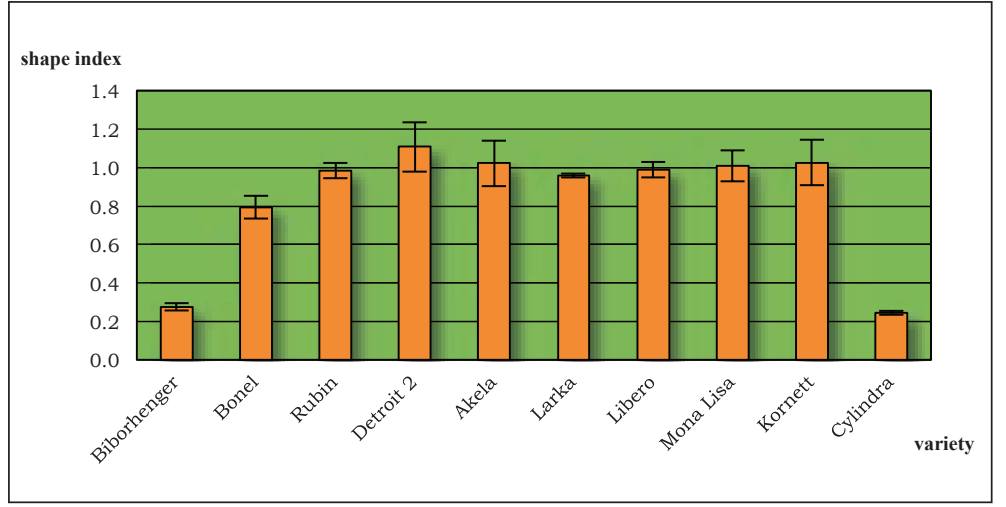

Figure 1. Shape index of the varieties - diameter $(\mathrm{cm}) /$ length $(\mathrm{cm})$

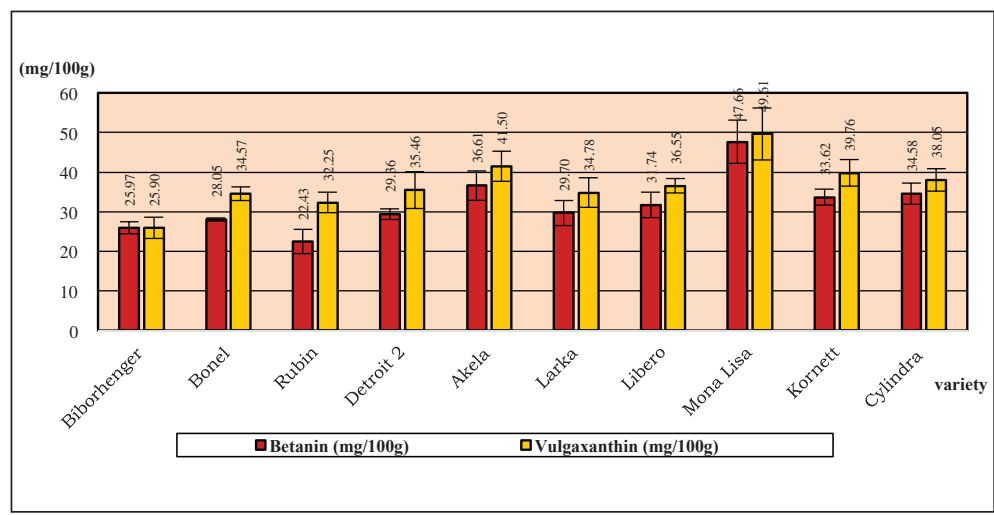

Figure 2. Betanin content (mg/100g) of beetroot varieties

Table 2. Correlation studies between beetroot quality parameters $(n=30)$

\begin{tabular}{|c|c|c|c|c|c|c|c|}
\hline & $\begin{array}{c}\text { Total } \\
\text { solids } \\
\text { content } \\
(\%)\end{array}$ & $\begin{array}{c}\text { Betanin } \\
(\mathrm{mg} / 100 \mathrm{~g})\end{array}$ & $\begin{array}{l}\text { Vulgax- } \\
\text { anthin } \\
(\mathrm{mg} / 100 \mathrm{~g})\end{array}$ & $\begin{array}{c}\mathrm{BC} / \mathrm{BX} \\
\text { ratio }\end{array}$ & $\begin{array}{c}\text { Total } \\
\text { polyphenol } \\
\text { content } \\
(\mathrm{mg} / 100 \mathrm{~g})\end{array}$ & $\begin{array}{l}\text { Flavonoid } \\
\text { content } \\
(\mathrm{mg} / 100 \mathrm{~g})\end{array}$ & $\begin{array}{l}\mathrm{NO}_{3}-\mathrm{N} \\
(\mathrm{mg} / \mathrm{kg})\end{array}$ \\
\hline $\begin{array}{l}\text { Total solids } \\
\text { content }(\%)\end{array}$ & & 0.249 & 0.191 & 0.217 & -0.019 & 0.268 & -0.211 \\
\hline $\begin{array}{l}\text { Betanin } \\
(\mathrm{mg} / 100 \mathrm{~g})\end{array}$ & & & 0.898 & 0.457 & 0.500 & 0.367 & -0.476 \\
\hline $\begin{array}{l}\text { Vulgax- } \\
\text { anthin } \\
(\mathrm{mg} / 100 \mathrm{~g})\end{array}$ & & & & 0.025 & 0.592 & 0.551 & -0.458 \\
\hline $\mathrm{BC} / \mathrm{BX}$ ratio & & & & & -0.093 & -0.301 & -0.170 \\
\hline $\begin{array}{l}\text { Total } \\
\text { polyphenol } \\
\text { content } \\
(\mathrm{mg} / 100 \mathrm{~g})\end{array}$ & & & & & & 0.687 & -0.268 \\
\hline $\begin{array}{l}\text { Flavonoid } \\
\text { content } \\
(\mathrm{mg} / 100 \mathrm{~g})\end{array}$ & & & & & & & -0.481 \\
\hline $\begin{array}{l}\mathrm{NO}_{3}-\mathrm{N} \\
(\mathrm{mg} / \mathrm{kg})\end{array}$ & & & & & & & \\
\hline
\end{tabular}

Beside the red betanin the second most important pigment component is the yellow vulgaxanthin which can play an active role in reducing inflammation and detoxify the human body. Mona Lisa and Akela showed the highest (red and yellow) pigment content during the sensory evaluation (Figure 2).

Mabry (1980) reported that the biosynthesis of red and yellow pigments started from the same compound

(betalamic acid) and run parallel to each other which can give an explanation for the similar accumulation $(\mathrm{r}=0.898)$ of the two pigments (Table 2).

Beside the pigment content other bioactive compounds are important as total polyphenols and flavonoids which have has a medium intensity correlation $(\mathrm{r}=0.687)$ between their accumulations (Table 2).

Polyphenols can protect the human body from chronic disease by their anti-inflammatory and antioxidant effects 
(Smith \& Charter, 2011). Higher total polyphenol content was measured ( $>70 \mathrm{mg} \mathrm{GAE} / 100 \mathrm{~g})$ in Akela, Mona Lisa and Bonel genotypes (Figure 3). Similar trends were observed as regards to total flavonoid content. In this case the same varieties (Akela, Mona Lisa and Bonel) had shown higher values (>20 mg $\mathrm{CE} / 100 \mathrm{~g})$. These varieties could be excellent not only for fresh market but also processing industry.

The consumption of fresh vegetables has shown more interest which determine the importance of the examination of taste. Water soluble solids have a considerable part of sugars which are in correlation with the sweet taste of the root. Water soluble solids were determined by Brix meter. Raw beetroots were also evaluated sensorially (1-5). Beside the sweet taste the presence of geozmin causing an earthy taste could also be evaluated by chewing raw beetroot slices. The earthy taste is due to microorganisms living in symbiosis with the roots, to the genetical character of the variety but also to soil factors as airless soil which play a part in its development.

The highest ref. \% was measured in Akela (7.15\%) and Mona Lisa (6.43\%) (Figure 4).

Low nitrate content can be found in the leaf and root of beetroot which is not toxic or harmful but can cause problems. Therefore the higher nitrate content is not acceptable for fresh market and processing industry neither. In our conditions values below $900 \mathrm{mg} / \mathrm{kg}$ (Figure 5) were examined in all of the varieties which is favourable in the case of beetroot. Ninfali \& Angelino (2013) confirmed that during the fermentation of beetroot the nitrate content can decrease significantly.

In summary the Mona Lisa, Akela and Larka excelled in all of the examined quality parameters as pigment-, total polyphenol- and flavonoid contents.

\section{Conclusions}

To conclude we can state that significant differences were found in morphological and quality parameters between the varieties. Mona Lisa, Akela and Larka are recommended primarily for fresh market due to their excellent quality parameters. Other examined varieties can satisfy processing requirements during autumn as canned salad, beetroot juice and beetroot powder. According to health care and high curative ability of beetroot, it should be consumed as fresh and processed form through the year.

\section{References}

Abrankó, L., Dernovics, M., Fodor, M., Gyepes, A., Szatura, ZS., Woller, Á. (2010): Hagyományos, gyors és automatizált módszerek alkalmazása élelmiszerek kémiai vizsgálatára. Nemzeti Tankönyvkiadó, Digitális Tankönyvtár. TAMOP 4.2.5 Book Database.

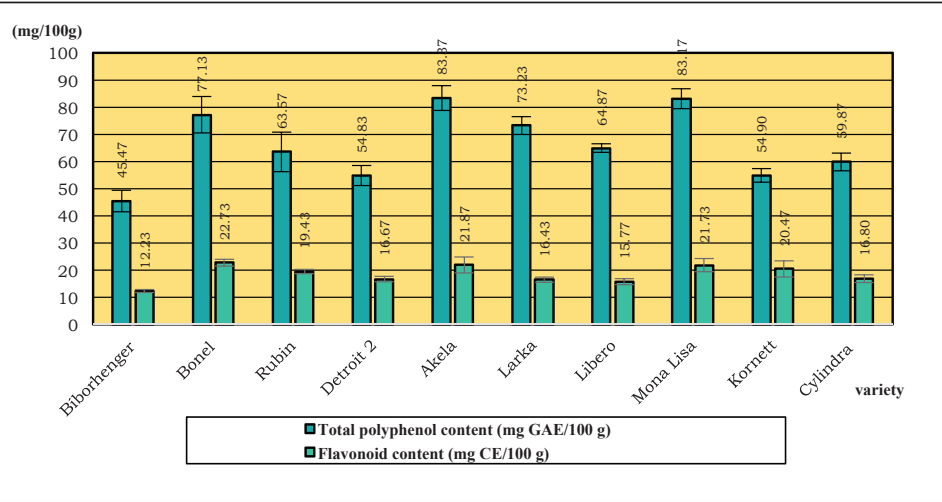

Figure 3. Total polyphenol and flavonoid contents $(\mathrm{mg} / 100 \mathrm{~g})$ of the beetroot varieties

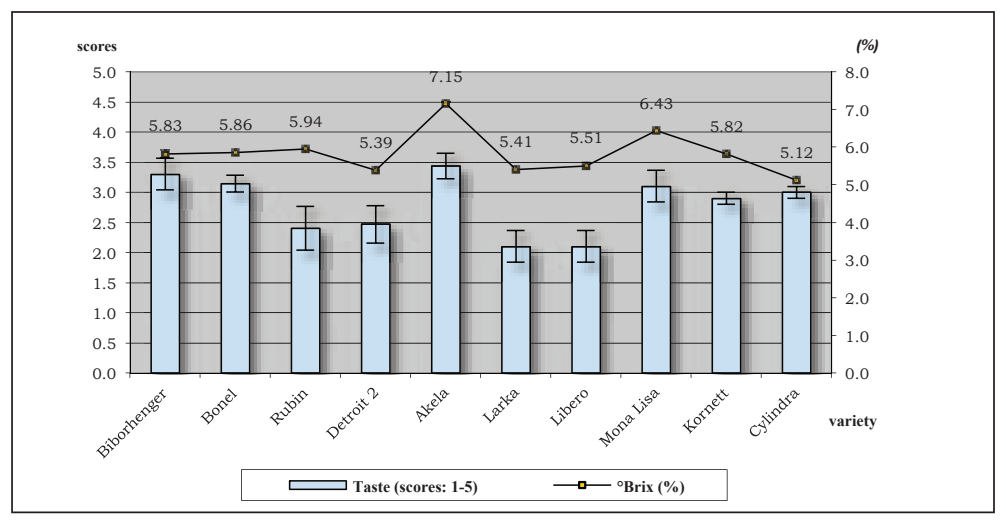

Figure 4. The taste (1-5) and the water soluble solids content (\%) of the examined varieties

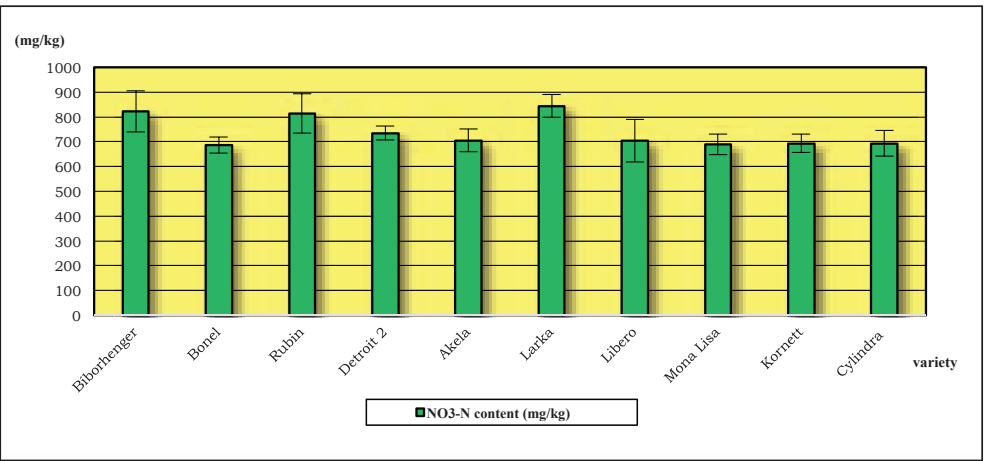

Figure 5. Nitrate content $(\mathrm{mg} / \mathrm{kg})$ in the different varieties

Bailey, S. J., Winyard, P., Vanhatalo, A., Blackwell, J. R., DiMenna, F. J., Wilkerson, D. P., Tarr, J., Benjamin, N., Jones, A. M. (2009): Dietary nitrate supplementation reduces the $\mathrm{O} 2$ cost of low-intensity exercise and enhances tolerance to high-intensity exercise in humans. Journal of Applied Physiology. Vol. no. , DOI: 10.1152/japplphysiol.00722.2009

Bryan, N. S., Pierini, C. (2013): Beet the Odds. Harness the power of beets to radically transform your health. Neogenis. U.S.A. 46 p.

Ferenczi, S. (1970): Rote Bete in der Zusatherapie bei Kranken mit Bösartigen Neubildungen. Heidelberg, Haug. 182. p.

Green, W. (2011): The Greatest Guide to Slimming \& Healthy Living. Greatest Guides. 160 p.

Hraskóné, Tóthné Taskovics, ZS. (2011): A gyökérzöldségek jelentősége. In Gyökérzöldségek termesztése. Szerk.: KOVÁCS A., Mezőgazda Kiadó, Bp. 7-12. 
Hyun, K., Yun-Jung, B., Mi-Kyeong, C., Yoon-Sok, C. (2009): Silicon Supplementation Improves the Bone Mineral Density of Calcium-Deficient Ovariectomized Rats by Reducing Bone Resorption. Biological Trace Element Research. 128 (3): 239-247.

Kapil, V., Milsom, A. B., Okorie, M., Maleki-Toyserkani, S., Akram, F., Rehman, F., Arghandawi, S., Pearl, V., Benjamin, N., Loukogeorgaki, S., Macallister, R., Hobbs, A. J., Webb, A. J., Ahluwalia, A. (2010): Inorganic Nitrate Supplementation Lowers Blood Pressure in Humans: Role for Nitrite-Derived NO. In Hypertension. 56: 274-281.

Lamaison, L., Carnat, A. (1990): Teneurs en acide rosmarinique, en dérivés hydroxycinnamiques totaux et activités antioxydantes chez les Apiacées, les Borraginacées et les Lamiacées médicinales. Pharm Acta Helv. 65: 315-320.

Mabry, T. J. (1980): Betalains. In Encyclopedia of plant physiology, newseries, vol.8. Secondary plant products. (Bell E. A., Charlwood, B. B., Edies.). Springer-Verlag, New York, 513-533 p.

Nilsson, T. (1970): Studies into the pigments in beetroot. Lantbr. högsk. Anner. 36: 179-219.
Ninfali, P., Angelino, D. (2013): Nutritional and functional potential of Beta vulgaris cicla and rubra. In Fitoterapia. 89: 188-199.

Presley, T. D., Morgan, A. R., Bechtold, E., Clodfelter, W., Dove, R.W., Jennings, J. M., Kraft, R. A., King, S. B., Laurienti, P. J., Rejeski, W. J., Burdette, J. H., Kim-Shapiro, D. B., Miller, G. D. (2011): Acute effect of a high nitrate diet on brain perfusion in older adults. In Nitric Oxide. 24 (1): 34-42.

Samman, S., Sivarajah, G., Man, J. C., Ziaul, I. A., Petocz, P., Caterson, I. D. (2003): A Mixed Fruit and Vegetable Concentrate Increases Plasma Antioxidant Vitamins and Folate and Lowers Plasma Homocysteine in Men. Journal of Nutrition. 133 (7): 2188-2193

Smith, J., Charter, E. (2011): Functional Food Product Development. Hui: Food Science and Technology. John Wiley \& Sons. 528 p.

Takácsné Hájos, M. (2009): Cékla. In Zöldségtermesztés szabadföldön. Szerk.: Hodossi S., Kovács A., Terbe I., Slezák K. Mezőgazda Kiadó, Bp., 270-275.

Takácsné Hájos, M. (2011): Cékla termesztése. In Gyökérzöldségek termesztése. Szerk.: Kovács A., Mezőgazda Kiadó, Bp. 87-107. 